IZA DP No. 7451

Getting Stuck in the Blues:

Persistence of Mental Health Problems in Australia

John Roy

Stefanie Schurer

June 2013 


\title{
Getting Stuck in the Blues: Persistence of Mental Health Problems in Australia
}

\author{
John Roy \\ Victoria University of Wellington \\ Stefanie Schurer \\ Victoria University of Wellington \\ and IZA
}

Discussion Paper No. 7451

June 2013

IZA

P.O. Box 7240

53072 Bonn

Germany

Phone: +49-228-3894-0

Fax: +49-228-3894-180

E-mail: iza@iza.org

Any opinions expressed here are those of the author(s) and not those of IZA. Research published in this series may include views on policy, but the institute itself takes no institutional policy positions. The IZA research network is committed to the IZA Guiding Principles of Research Integrity.

The Institute for the Study of Labor (IZA) in Bonn is a local and virtual international research center and a place of communication between science, politics and business. IZA is an independent nonprofit organization supported by Deutsche Post Foundation. The center is associated with the University of Bonn and offers a stimulating research environment through its international network, workshops and conferences, data service, project support, research visits and doctoral program. IZA engages in (i) original and internationally competitive research in all fields of labor economics, (ii) development of policy concepts, and (iii) dissemination of research results and concepts to the interested public.

IZA Discussion Papers often represent preliminary work and are circulated to encourage discussion. Citation of such a paper should account for its provisional character. A revised version may be available directly from the author. 


\section{ABSTRACT \\ Getting Stuck in the Blues: Persistence of Mental Health Problems in Australia*}

Do episodes of mental health problems cause future mental health problems, and if yes, how strong are these dynamics? We quantify the degree of persistence in mental health problems using nationally-representative, longitudinal data from Australia and system GMM-IV and correlated random effects approaches are applied to separate true from spurious state dependence. Our results suggest only a moderate degree of persistence in mental health problems when assuming that persistence is constant across the mental health distribution once individual-specific heterogeneity is accounted for. However, individuals who fell once below a threshold that indicates an episode of depression are up to five times more likely to experience such a low score again a year later, indicating a strong element of state dependence in depression. Low income is a strong risk factor in state dependence for both men and women, which has important policy implications.

JEL Classification: $\quad 114, \mathrm{C} 23$

Keywords: mental health, depression and anxiety, dynamic panel data models, GMM-IV, HILDA

Corresponding author:

Stefanie Schurer

Victoria University of Wellington

School of Economics and Finance

Wellington 6041

New Zealand

E-mail: stefanie.schurer@vuw.ac.nz

\footnotetext{
* Many thanks for invaluable comments from Dean Hyslop, Jinhu Li, Anirban Basu, Maarten Lindeboom, and participants of the research project workshop of the School of Economics and Finance, Victoria University of Wellington and the Third Australasian Econometrics and Health Economics workshop. This paper uses unit record data from the Household, Income and Labour Dynamics in Australia (HILDA) Survey. The HILDA Project was initiated and is funded by the Australian Government Department of Families, Housing, Community Services and Indigenous Affairs (FaHCSIA) and is managed by the Melbourne Institute of Applied Economic and Social Research (Melbourne Institute). The findings and views reported in this paper, however, are those of the authors and should not be attributed to either FaHCSIA or the Melbourne Institute.
} 


\section{NON-TECHNICAL SUMMARY}

Mental health problems are widely recognised as the leading cause of social and economic dysfunctioning. About $10 \%$ of the population in the Western world are diagnosed with depression and anxiety, the two major mental health disorders. These disorders are characterised by excessive worrying and gloomy thoughts, they tend to start early in life, and symptoms persist usually over many decades. It is not difficult to see why individuals who suffer from such emotional preoccupations are less likely to invest in their education and health, less successful in the labour market, and accumulate exorbitant health care costs throughout their lives. What is less obvious is the question why symptoms of depression and anxiety are so chronic in nature. This study hypothesises that a first-time experience of an episode of depression or anxiety will alter an individual's way of thinking and behaviour which causes the individual to get trapped in a vicious cycle of continuously experiencing such symptoms in the future. If this is the case, then treating such first episode will be crucial in averting the excessive long-term economic and social costs associated with chronic mental health problems. Our study finds that experiencing an episode of depression or anxiety doubles the probability of experiencing such an episode again in the next year. Low household income is a major risk factor in this "state dependence", as it increases this probability by almost $500 \%$. We suggest that public policy makers in Australia should increase the hours of free counselling services currently provided to individuals suffering from depression or anxiety (currently 10 per year), and should target in particularly individuals with low economic means. 


\section{Introduction}

Mental health is an integral component of human capital, one which is often taken for granted. The absence of mental health may have devastating effects on an individual's ability to lead a balanced professional, social, and family life. Among all possible mental illnesses, depression stands out as one of the most prevalent and prominent. One in two people will have at least one episode of depression in their lifetime (McGorry, 2005). People with depression experience feelings of misery, unhappiness, and hopelessness, and frequently they are combined with feelings of excessive worry and anxiety. ${ }^{1}$ These are not uncommon feelings, but for people with clinical depression they are so strong and permanent that they do not only interfere with daily life, but often entail suicide thoughts (Williams et al., 2010).

Part of what makes depression such a devastating disorder is that it develops early in life, and is characterised by a high rate of relapse of symptoms (Prager, 2009; Rutter, 2006; Klearman and Weissman, 1989). Each time a person is clinically depressed the chance of being depressed again is substantially increased (Farb et al., 2011). One of the major risk factors for repeat episodes is the presence of residual symptoms that persist after an episode ends. These residual symptoms tend to progress over time to another full-blown depressive episode, especially so if the sufferer was left without sustained treatment. Farb et al. (2011) suggests that the physiological changes in the brain chemistry caused by a first episode are likely to manipulate an individual's perception of risk, such that the individual becomes hypersensitive to external threats. An individual will then withdraw when feeling the blues at much smaller triggers than those that caused the first episode of depression. If this mechanism is true it would imply a vicious circle of recurring episodes of depression that deepen in severity over time. As a consequence of the early onset of depression and the strong persistence of their symptoms, affected individuals will live with the illness for most of their lives.

Rates of relapse are usually studied in clinical settings for patients with major depressive disorders who receive treatment (see Rucci et al., 2011, for an overview). However, unlike other chronic illnesses such as diabetes or asthma, not everyone who suffers

\footnotetext{
${ }^{1}$ It should be noted that whenever we talk about depression, we also include anxiety. The two illnesses cannot clearly be separated from each other, as most patients who present with symptoms of depression, also present with symptoms of anxiety, and vice versa (e.g. Gorman, 1996, and references therein).
} 
symptoms of depression seeks help. ${ }^{2}$ Studying a clinical sample under treatment has the disadvantage that it will most likely under-estimate the magnitude of the persistence and consequences of depression. Little empirical evidence exists on these dynamics using a sample of treated and non-treated individuals and comparing this sample to the average population. One exception is Hauck and Rice (2004) who estimate the persistence in mental health problems for a nationally-representative British sample. Their study finds that sudden drops in mental health appear to dissipate quickly over time.

Given the strong evidence of relapse of depression in a clinical setting, we find this to be a surprising result. Therefore, we will estimate the dynamics of mental health problems, which we use interchangeably for symptoms of depression (and anxiety), for a comparable, nationally representative Australian sample. We start out by investigating the persistence in both mental health problems that occur at any point in the distribution, similar to Hauck and Rice (2004), and then move on to estimate the effect for individuals at the lower end of the distribution. As for the possibility that the dynamics of mental health problems are heterogeneous, we report persistence estimates by socioeconomic status and age-groups.

The analysis is conducted with eight waves of the Household, Income, and Labour Dynamics of Australia (HILDA) Survey. A continuous measure of mental health is constructed from the five-item version of the Mental Health Inventory (MHI-5), which is part of the SF-36, a widely validated instrument that has been shown to reliably measure depression and anxiety (Butterworth and Crosier, 2004; Berwick et al., 1991). To estimate the degree of persistence in mental health problems, we follow the literature by including a lagged value of the dependent variable on the right-hand side of a mental health determination model. However, the estimated coefficient on this lagged dependent variable may be biased due to the presence of unobservable, time-invariant factors that influence in each time-period the level of mental health, a phenomenon referred to in the literature as spurious state dependence (Heckman, 1978). To identify true state dependence, i.e. a causal effect of changes in past on current mental health problems, we use a system GMM-IV approach (Arellano and Bond, 1991; Arellano and Bover, 1995). This approach allows for a potential correlation between unobserved heterogeneity and all regressors in the model, but it assumes that the persistence in mental health problems is constant across

\footnotetext{
${ }^{2}$ E.g. Groom et al. (2003) estimates that 62 percent of Australians with mental illness will not seek any form of treatment.
} 
the mental health distribution. We therefore re-estimate the degree of state dependence using a binary indicator that proxies episodes of depression. In this non-linear setting, we use a correlated random effects approach (Mundlak, 1978; Wooldridge, 2005, 2009) that is commonly used to estimate the dynamics of general health status and well-being (Heiss, 2011; Pudney, 2008; Contoyannis et al., 2004a,b).

Our results suggest only a moderate degree of persistence of mental health shocks that occur at any point in the mental health distribution, once unobserved heterogeneity is accounted for. A low persistence parameter in our data implies that individuals who experience an exogenous change in mental health, be it positive or negative, revert back to their long-term mental health equilibrium after 2-3 years. The empirically observed high correlation of mental health scores over time in the raw data is mainly due to an individual's propensity to report/experience a particular value of mental health in any time period. However, when estimating the persistence of a mental health shock at the lower end of the distribution, we find strong evidence for state dependence. Individuals who experienced an episode of depression in the past year are up to five times more likely to experience the same state again in the next time period. This holds especially so for individuals with lower than average household incomes.

\section{Data}

To conduct the empirical analysis, we use data from the Household, Income, and Labour Dynamics of Australia (HILDA) Survey (2001-2010). ${ }^{3}$ HILDA is an Australian, nationally representative panel study which collects social and economic data from annual interviews and questionnaires of persons aged 15 and older and follows the same individuals over time. The study started out with 13,969 completed interviews from 7,682 households in 2001. Our sample consists of participants for whom complete data on variables of interest and for at least three time periods are available between waves 3 and 10, which leaves us with a total of 4,968 men (20,302 person-year observations) and 5,718 women $(23,839$ person-year observations) in the GMM-IV analysis. On average, individuals are almost five years in the sample. About one-half of these individuals remain in the sample for all

\footnotetext{
${ }^{3}$ The HILDA Project was initiated and is funded by the Australian Government Department of Families, Housing, Community Services and Indigenous Affairs (FaHCSIA) and is managed by the Melbourne Institute of Applied Economic and Social Research (Melbourne Institute). More information about the survey is available in Summerfield (2010).
} 
eight years. ${ }^{4}$

\subsection{Dependent variable}

Mental health is measured with a composite indicator that is constructed from five questions of the Medical Outcomes Study Short Form (SF-36) questionnaire, one of the most widely used and validated self-completion measures of health status (Ware and Gandek, 1998). The five-item Mental Health Inventory (MHI-5) in the SF-36 instrument in HILDA shows good psychometric properties, with a high internal consistency (Cronbach's alpha) of 0.82 and a high correlation of 0.90 with the first underlying factor that is labelled as mental health (Butterworth and Crosier, 2004). The MHI-5 has been shown to be as good as more item surveys for detecting major depression, affective disorders, and generally, anxiety disorders (Berwick et al., 1991).

The five questions used for constructing the mental health index are: (1) Been a nervous person, (2) Felt so down in the dumps nothing could cheer you up, (3) Felt calm and peaceful, (4) Felt down, and (5) Been a happy person. Each interviewee was asked to rate how often they felt in such a way in the past four weeks: [1] All of the time, [2] Most of the time, [3] A good bit of the time, [4] Some of the time, [5] A little of the time, [6] None of the time. The mental health scale is obtained by summing the (reversed) answers to these five questions, subtracting 5 , dividing by 25 , and multiplying the sum by 100 (Butterworth and Crosier, 2004). The final measure ranges between 0 and 100, where 100 implies very good mental health and 0 a serious mental health problem. The magnitude of the 0-100 scale is not intuitive, therefore we standardise the scale with a mean of 0 , and a standard deviation of 1 . This measure of mental health is associated with symptoms of depression and anxiety, which we refer to in subsequent sections as mental health problems. Scores below 52 are considered to be predictive of episodes of depression (Silveira et al., 2005). We use a binary indicator for values below 52 as indicator for depression in the second part of our analysis.

There are several other measures of mental health and treatment regimes available in waves 7 (2007) and 9 (2009). One is a binary indicator of whether the individual

\footnotetext{
${ }^{4}$ Attrition in this sample causes a small amount of positive selection bias when linking the mental health score reported in 2001 with the probability of dropping out of the sample in subsequent years. People with worse mental health recorded in the year 2001 tend to be slightly more likely to drop out of the sample. If these are also the individuals for whom persistence tends to be stronger, then we will under-estimate the the persistence parameter. In a robustness check, we will test for this possibility by using a balanced sample only.
} 
has ever been diagnosed with depression or anxiety by a health care professional, and requires treatment for more than six months. This indicator is more accurate in detecting a mental health problem, since it implies that a medical professional has diagnosed the condition. The exact wording of the question is: "Have you ever been told by a doctor or nurse that you have any of the long-term health conditions listed below? Please only include those conditions that have lasted or are likely to last for six months or more: Anxiety/Depression". In addition, in wave 9 only (2009) individuals were asked in the continuing person questionnaire whether they have depression or anxiety in the context of a serious illness and whether they regularly see a doctor for this condition or take prescription medication for it. The exact wording of these questions are: "Have you ever been told by a doctor or nurse that you have any of the long-term health conditions listed below? Please only include those conditions that have lasted or are likely to last for six months or more" and "Do you take any prescription medications for this condition?". These indicators are used to complement the analysis and to assess the predictive validity of the MHI-5 score.

\subsection{Control variables}

Within our estimation framework, we also include three polynomials of age to account for general peaks and troughs in mental health that depend on the lifecycle in a nonlinear fashion. Socioeconomic status is measured by household income, education level, and occupational class. Household income (logarithmatised) is measured as the needsadjusted (by household size) disposable income deflated to 2001 prices. The participant's highest level of education is measured by indicator variables (left school after year 11, passed year 12, attained a university degree, attained a certificate (I-IV)). Labour market status is categorised as follows: not in the labour force (this includes students and stayat-home parents), retired, unemployed, professionals, legislators, technicians, workers in the service industry, craft (tradespeople), machine operators, skilled agricultural workers, and elementary workers (e.g. physical labour, cleaners). Further, we include indicators that pick up the remoteness of the region in which the participant lives (major city, inner regional, outer regional, remote), marital status (married, never married or de facto, divorced, widowed), the number of people living in the household, the number of children in the household and ethnicity (of European origin or otherwise). This is a commonly used set in estimating the dynamics of health (Hauck and Rice, 2004; Contoyannis et al., 
2004a,b). Last, to control for temporary fluctuations in the self-reports of mental health, we further control for the following six life events, which an individual experienced during the past year: (1) Lost a close friend; (2) lost a relative; (3) lost a spouse or child; (4) separated from spouse; (5) being fired or made redundant; and (6) having given birth to a child. Descriptive statistics of all control variables are presented in Table A.1 in the Appendix.

\section{Empirical framework}

We model the autoregressive nature of mental health $\left(Y_{i t}\right)$ as follows:

$$
Y_{i t}=\gamma Y_{i t-1}+X_{i t}^{\prime} \beta+\alpha_{i}+u_{i t}
$$

where $i=1, \ldots, N$ and $t=1, \ldots, 9, Y_{i t-1}$ is a lagged value of the dependent variable, $\gamma$ measures the degree to which exogenous, past changes in mental health affect today's mental health, $X_{i t}^{\prime}$ is a vector of observable characteristics including a constant. All remaining variation in mental health is captured by $\alpha_{i}$, an individual-specific effect, and $u_{i t}$, an idiosyncratic error term. Both are assumed to be distributed with mean zero and constant variance $\left(\sigma_{\alpha}^{2}, \sigma_{u}^{2}\right)$. The error term $\alpha_{i}$ captures all time-invariant, individualspecific variations in mental health that cannot be explained by the included control variables $X_{i t}^{\prime}$. Some examples for $\alpha_{i}$ are a genetic disposition to mental health problems, the regular and excessive consumption of addictive, or hallucinogenic drugs that have been linked to the onset of mental disorders (American Psychiatric Association, 2000), or systematic differences in the reporting of one's own mental health (Bago d'Uva et al., 2008). All these factors are unobserved in the data-set used for the empirical application.

If $\alpha_{i}$ is not correlated with the regressors (random effect) or with the initial mental health status, then (1) can be estimated with a generalised least squares (GLS) approach to obtain unbiased coefficient estimates and standard errors (Wooldridge, 2009). It is more likely, however, that the unobserved heterogeneity is correlated with the regressors of the model, i.e. $E\left(X_{i t}, \alpha_{i}\right) \neq 0$ or, because of the autoregressive nature of the model, with initial mental health $E\left(Y_{i 0}, \alpha_{i}\right) \neq 0$. In this case, the GLS estimates of $\beta$ or $\gamma$ are biased and inconsistent. We specify a correlated random effects (CRE) model that assumes that the individual specific effect is linearly correlated with the regressors of the 
model and the initial endowment of mental health $\left(Y_{i 0}\right):^{5}$

$$
\alpha_{i}=\bar{X}_{i}^{\prime} \delta+\omega Y_{i 0}+v_{i}
$$

where $v_{i}$ is a true random effect. Mundlak (1978) has shown that the CRE estimator is equivalent to the FE estimator, if Eq. (2) is correctly specified and its coefficient of variation approaches 1 . In this case Eq. (3) can be estimated by GLS:

$$
Y_{i t}=\gamma Y_{i t-1}+X_{i t}^{\prime} \beta+\bar{X}_{i}^{\prime} \delta+\omega Y_{i 0}+v_{i}+u_{i t}
$$

The parameter $\gamma$ in Eq. (3) measures the degree to which an exogenous one-unit change in past mental health, which we will refer to as a shock, affects contemporaneous mental health $(t)$, but also the long-term mental health level. If $\gamma=0$, the effect of a past mental health shock fully dissipates within two time-periods. If $0<\gamma \leq 1$, then a past mental health shock will be passed on to future mental health states in the magnitude of $\gamma$. In the extreme, $\gamma=1$ implies that the individual will never fully revert to his or her long-term mental health state. Negative values of $\gamma$ describe a counter-cyclical pattern of mental health outcomes over time, which is rather unlikely (e.g. Heiss, 2011).

However, if Eq. (3) is incompletely/incorrectly specified with respect to $\alpha_{i}$, but estimated with GLS, then $\gamma$ would capture not only state dependence, but also the persistence in mental health due to the fixed component, which is sometimes referred to as spurious state dependence (Heckman, 1978). True state dependence describes the situation where the experience of a mental health shock will result in a change of attitudes, preferences or anything relevant to future experience of that event, in contrast to spurious state dependence, which means that unobserved factors, that correlate over time, make the event more likely in each time-period (Hsiao, 2003, p. 216). ${ }^{6}$ In our case, true state dependence is given when the experience of an exogenous drop in mental health causes a change in the individual's perception and anxiety that makes ill mental health tomorrow more likely.

\footnotetext{
${ }^{5}$ We follow here the simplified approach proposed by Wooldridge (2005). Alternative, and computationally more demanding specifications of the dependence structure of $\alpha_{i}$ are possible, however, Arulampalam and Stewart (2009) have shown that the simplified approach performs equally well in non-linear dynamic models.

${ }^{6}$ Strictly speaking, the notion of state dependence as described in Heckman (1978) refers to dynamics in binary choice models that are commonly used in the treatment effects literature. A classic study is, for instance, Card and Sullivan (1988) who investigate the dynamics of unemployment. We are aware of the nomenclature, but borrow the concept for our linear models, with the sole intention to abbreviate labels.
} 
Spurious state dependence would mean that an individual's characteristics that remain constant over time increase the probability of (reporting) a mental health problem in every time-period.

To deal with unobserved heterogeneity with less restrictive assumptions than stated in Eq. (2), our preferred model to estimate Eq. (3) is a system GMM approach. It takes first-differences of Eq. (1) to purge the individual-specific effect $\alpha_{i}$ from the model:

$$
\Delta Y_{i t}=\gamma \Delta Y_{i t-1}+\Delta X_{i t}^{\prime} \beta+\Delta u_{i t}
$$

As estimating Eq. (4) with OLS would lead to an under-estimate of $\gamma$ due to the negative correlation between $\Delta Y_{i t-1}=\left(Y_{i t-1}-Y_{i t-2}\right)$ and $\Delta u_{i t}=\left(u_{i t}-u_{i t-1}\right)$, we instrument for $\Delta Y_{i t-1}$. A valid and strong instrument requires to be uncorrelated with $\Delta u_{i t}$, but strongly correlated with $\Delta Y_{i t-2}$. Arellano and Bond (1991) suggest a general methods of moments (GMM) approach to estimate $\gamma$. What we will refer to as the GMM-IV estimator exploits the following moment conditions:

$$
E\left(Y_{i s} \Delta u_{i t}\right)=0 \forall s \leq t-2
$$

These conditions imply that all subsequent lags of $Y_{i t-j}$ for $j \geq 2$ and $t \neq s$ can be used as valid instruments $\left(Z_{i}\right)$ for $\Delta Y_{i t-1}$, since $\Delta u_{i t}$ is orthogonal not only to $Y_{i t-2}$, but also to $Y_{i t-3}, Y_{i t-4}$, and so on. In addition, if all $X_{i t}^{\prime}$ s are strictly exogenous, then all lead and lagged values of $X_{i t}^{\prime}$ can be used as valid instruments. This estimation method requires the availability of at least three time periods. ${ }^{7}$ The total number of instruments may become very large as $Z_{i}$ is a matrix with dimension of $(T-2) \times((T-2)+(K \times T))$, where $K$ is the number of regressors in $X_{i t}^{\prime}$. Less instruments are available if one assumes that some of the $X_{i t}$ are not strictly exogenous. It is possible that some covariates $W_{i t} \in X_{i t}$ are predetermined, i.e. $E\left(W_{i t+s} \Delta u_{i t}\right) \neq 0$ for $s \geq 0$, so only their lagged values can be used as valid instruments. We assume that unemployment, education, and income are predetermined. The GMM-IV estimator is unbiased and consistent under the assumption of no second-order serial correlation in the error term. To test this assumption, we use a test procedure outlined in Arellano and Bond (1991). GMM-IV can be used for time

\footnotetext{
${ }^{7}$ Alternatively, one could use the lagged changes in $Y_{i t}$ as additional moment conditions in a level equation, as suggested by Blundell and Bond (1998) and Arellano and Bover (1995). We estimated our model with both approaches but they yielded similar estimates for $\gamma$ and test statistics. These are provided upon request.
} 
periods of $\mathrm{T} \geq 3$, as identification comes from large $\mathrm{N}$, and not from large $\mathrm{T}$, and in unbalanced panels.

One disadvantage of the linear dynamic model is its assumption that persistence is equally strong at any point of the mental health distribution and that positive and negative shocks to mental health have symmetric effects. Therefore, $\gamma$ would not only measure the magnitude to which an individual gets stuck in the blues (a negative shock that pushes the individual lower in the distribution), but also the magnitude of getting stuck in eternal bliss (a positive shock pushes the individual higher in the distribution). From a policy perspective it is more interesting to learn about the strength of state dependence at the lower levels of the mental health distribution. We therefore also estimate the probability of ending up again in an episode of depression (MHI-5 score $<52$ ) after having experienced the condition in the past time period. The same correlated random effects approach (GLS) as outlined in Eq. (3) is used for estimation except for that $Y_{i t}$ and $Y_{i t-1}$ are now binary choice variables (linear probability model).

\section{Distribution and inter-temporal correlation of mental health}

Figure 1 describes the distribution of the mental health score (MHI-5) for women (black lines) and men (grey lines). The sample average is around 75 points on a scale from 0 to 100 , with a standard deviation of 17 points. The distribution is highly skewed to the left, suggesting that a large proportion of individuals consider themselves in good mental health. Only 16 percent of the sample score lower than one standard deviation below the mean (MHI-5 score < 58). According to a Kolmogorov-Smirnov test, we reject the null hypothesis that the distribution of mental health between men and women is identical $(\mathrm{p}<0.001)$. This is one reason to conduct the subsequent analysis separately for men and women. The histogram brings attention to the fact that the mental health measure is not strictly continuous, but we approximate it with a linear model, since there are 50 distinct values, which would make modelling in a non-linear fashion less manageable. Such a simplification is used widely in the applied well-being literature. ${ }^{8}$

Among women, 19 percent of the sample state that they have ever been diagnosed with

\footnotetext{
${ }^{8}$ Using a linear modelling approach for inherently ordinal data goes back to Ferrer-i-Carbonell and Frijters (2004) who show that estimation results are almost identical if one uses a linear versus a nonlinear specification to estimate the socio-economic gradient of well-being, where the self-assessed wellbeing measure takes 11 different values. In our case, we have 50 distinct values, almost five times as many data points.
} 
depression or anxiety, which requires treatment, whereas only 12 percent of men make the same claim (data from 2007 and 2009). Not all of these are currently suffering from an episode of depression or anxiety. For whom we have data from 2009, 12 percent of women and 7 percent of men claim that they have been officially diagnosed with depression and/or anxiety and which is currently a problem. Half of these are currently taking prescription medicine to deal with the condition and 5/6 of women and $3 / 4$ of men are currently seeing a doctor for it (see Table A.1 in the Appendix). Interestingly, 9 percent of women and 7 percent of men in the sample have a MHI- 5 score that lies below 52 , which is the recommended cut-off value to screen for depressive disorders. These two numbers match the 12 percent of women and 7 percent of men who reported to currently suffer from and were diagnosed with depression or anxiety. This is evidence that the MHI-5 mental health cut-off value has predictive power in identifying individuals who suffer from such mental health problems. ${ }^{9}$

Table 1 reports the average correlations of mental health scores across the nine time periods available pooling the sample of men and women. The correlations are the strongest between any two adjacent time periods and then decline steadily at a decreasing rate. For instance, the average correlation between two time periods ranges between .61 and .64, depending on the year/wave, when the data was recorded. The average period-to-period correlations may differ over time either because the sample slightly changes from wave to wave, because of aggregate mental health shocks that may be the results of economic downturns, or because individuals become more familiar with completing the survey. The further the time periods apart the smaller are the inter-temporal correlations. The rates of decline taper off until they stabilise around 0.5. This is indicative of a strong permanent component in (reporting) mental health scores.

\section{[Insert Table 1 here]}

Another way of gauging the magnitude of persistence in mental health states is to look at the transition probabilities between these states. Table 2 displays the average

\footnotetext{
${ }^{9}$ We investigated whether our measure of mental health corresponds to binary measures of being ever diagnosed with depression/anxiety or ever diagnosed but currently prevailing condition. Individuals in the sample who report they were diagnosed with, and currently suffer from, depression/anxiety, are four times as likely to be in the lowest mental health score quintile (average score of 48.5) than individuals who are not suffering from the condition. Similarly, individuals who do not suffer from the condition currently are eight times as likely to be in the highest quintile of the mental health score (average score of 94). A large fraction of individuals who are located in the lowest quintile of mental health are not diagnosed with depression (31 percent of all individuals who are not diagnosed).
} 
probability of staying within the same quintile of mental health (entries in the main diagonal) and the average probability of changing across the quintiles between time period $t$ (rows) and $t-1$ (columns). These probabilities are constructed as average over all nine adjacent time periods. Several observations are worth noting. First, the probability to stay in the same quintile of mental health is the highest for individuals in the lowest and in the highest quintile. For instance, individuals in the lowest mental health quintile in $t-1$ have a chance of almost 60 percent to stay in this quintile in the next time period $(t)$, whereas individuals in the highest quintile have a chance of 54 percent to remain in the same quintile in the next year. Much smaller are the staying probabilities in the middle of the mental health distribution, ranging between 30 and 40 percent. A second interesting observation is that it is a very rare phenomenon that individuals switch between the extreme ends of the mental health distribution. Only 2-3 percent of individuals in the sample are observed to switch between these two extremes. These raw transition probabilities indicate that persistence involves both getting stuck in the blues and getting stuck in eternal bliss.

\section{[Insert Table 2 here]}

\section{Estimation results}

The above figures refer to the raw persistence estimates only, which do not distinguish between the permanent component of mental health and true state dependence. In this section, we carefully separate out the differential contributions of unobserved heterogeneity and state dependence to these persistence estimates. Table 3 reports the estimation results of the main variables of interest for men and women, respectively, while full estimation results are reported in Table A.2 in the Appendix. Our preferred estimation model includes two lags of the dependent variable, and in the Arellano-Bond estimator we assume that all socioeconomic status variables are only weakly exogenous. We experimented with several different model specifications including one lag of the dependent variable, and allowing all control variables to be strictly exogenous, but in these cases we find second order serial correlation and/or lacking evidence of exogeneity of the instruments. Results on these alternative model specifications and test statistics are reported in Table A.3 in the Appendix. When including two lags of the dependent variable, both tests 
of no second-order serial correlation in the residuals and of over-identification are passed at the 5 percent level of confidence or better. All presented estimates are interpreted in terms of standard deviations (SD).

\section{[Insert Tables 3 here]}

Column 1 reports the results for our preferred specification of the Arellano-Bond estimator. A 1 SD exogenous drop (increase) in mental health in the past period leads to a $0.10 \mathrm{SD}$ drop (increase) in mental health in the current time period for both men and women. Experiencing a $1 \mathrm{SD}$ drop in mental health in each of the past two years is associated with a $0.12 \mathrm{SD}$ (0.13 SD for women) decrease in today's mental health. These estimates are substantially different from $1 \mathrm{SD}$, which would be the value for which positive or negative shocks to mental health alter the equilibrium level of mental health indefinitely. One can see this easily from the simulated path of mental health as outlined in Figure 2. ${ }^{10}$ Assume that the individual experiences a negative mental health shock in time period 5 in the magnitude of a drop in mental health by $1 \mathrm{SD}$. After one time period the individual reverts back almost fully to his or her long-term mental health state. From time period 8 onwards the individual reaches again his or her long-term equilibrium. These simulations show that mental health shocks, independent of the level of mental health, dissipate fully after three years. It is important to note that the same adjustment path occurs if the individual had experienced a positive mental health shock: Sudden improvements in mental health do not lead to a higher mental health equilibrium.

\section{[Insert Figure 2 here]}

There are several explanations for why the persistence parameters obtained from the GMM-IV method may be an under-estimate of the degree of persistence in mental health problems. On the one hand, it may be likely that the inclusion of individuals, who are currently in treatment for their mental health problem, and whose mental health score significantly improved across two time periods, down-ward biases the persistence parameter. When excluding all individuals who were observed to have taken prescription

\footnotetext{
${ }^{10}$ To calculate the first time period of the mental health path we used the average mental health score reported in the first time period in which the individual is observed. The mental health score is centered around 0 .
} 
drugs for depression or anxiety in 2009, the persistence parameters for lag 1 and 2 increases to 0.110 (SE 0.013) and 0.035 (SE 0.010) for women and to 0.100 (SE 0.015) and 0.022 (SE 0.010) for men. Although the persistence parameters are not dramatically larger, they support the hypothesis.

On the other hand, the inclusion of choice variables such as household income, education, or occupation, that have a high degree of serial correlation over time may lead to an under-estimate. Re-estimating the model only with polynomials of age, family status, life events, and time-dummy variables, the persistence parameters for women are 0.127 (SE 0.013) for lag 1 and 0.034 (SE 0.009) for lag 2. For men these are 0.140 (SE 0.015) for lag 1 and 0.038 (SE 0.010) for lag 2. Still, these estimates are far off from 1 SD.

A third explanation for the low persistence parameters is that the GMM-IV approach uses only within-individual variation in mental health. If an individual experiences a shock to mental health in one time period and reports the exact same mental health score in all following time periods, then this individual would not be included in the analysis. Therefore, it is worth considering the estimated persistence parameter obtained from the correlated random effects model which exploits between-individual in addition to the within-individual variation. In our case, the persistence parameters are 0.299 (SE 0.009 ) for men and 0.320 (SE 0.008) for women (see column 2 of Table 3). These are three times larger than the the GMM-IV estimates, but only half the size of the OLS estimates, and still far off from 1 SD.

Finally, the GMM-IV may yield an under-estimate because its linear specification assumes that the persistence in mental health is constant across the mental health distribution. It implies that negative shocks to mental health experienced by a very healthy individual have the same disequilibrium effect as negative shocks experienced by a sick individual. It is however more likely that individuals get thrown off their long-term mental health path when this shock is experienced at the lower end of the mental health distribution. For this reason, we investigate the degree of state dependence for individuals experiencing very low levels of mental health, i.e. a mental health score that lies below a medically relevant threshold (MHI-5 score $<52$ ), which we refer to as an episode of depression/anxiety. Note that for ease of exposition we will interpret the results in terms of depression only. We also test whether state dependence differs by socioeconomic status and age. Table 4 reports the estimated state dependence parameters for the probability of experiencing an episode of depression (Full estimation results are reported in Table 
A.2). All estimated coefficients are obtained from linear probability models that control for all variables described in Table A.1. To control for unobserved heterogeneity that may linearly correlate with the right-hand-side variables and the initial mental health state, we include the mean values of all time-varying variables and the initial period value of the dependent variable as described in Eqs. (2) and (3). Similar to the preferred GMM-IV model, we include two lags of the dependent variable. The state dependence parameter is interpreted as the probability change in experiencing an episode of depression today due to having experienced such an episode in the past.

For men and women, the state dependence parameter for the first lag of depression is 17 and 18 percentage points (significant at the 1 percent level, column (1)). Given the base probabilities of experiencing depression in the sample are 7.3 percent for men and of 9.35 percent for women, the percentage point change implies for men an increase in the chance of experiencing again an episode of depression by 228 percent for men and 191 percent for women. This increase in probability is almost doubled for men and women who experienced episodes of depression in each of the past two years. Note that these estimates are up to 50 percent larger when considering a balanced sample (see column (2)), suggesting that systematic attrition will downward bias the persistence parameters. Excluding all individuals who regularly consult a doctor for their condition, and therefore may have improved their mental health does not alter the conclusions (column (3)). The estimated persistence parameters are almost identical for men and about 15 percent smaller for women.

\section{[Insert Table 4 here]}

Is there heterogeneity in the state dependence of depressive symptoms? Are individuals with greater economic means more likely to buffer the experience of depressive symptoms? Columns (4) and (5) report the state dependence estimates for individuals who have household incomes that lie below or at, and above the median income, respectively. There are marked differences between the two groups. For men and women with lower household incomes the cumulative state dependence parameters over two time periods are 13 and 17 percentage points greater than the parameters for men and women with above-median incomes. For instance, the probability of ending up again with depressive symptoms after having experienced these symptoms in the last two years is 32.2 (39) percentage points 
for men (women) in the below-median income group, whereas for men (women) in the above-median income group it is 19.2 (22.2) percentage points.

Surprisingly, the state dependence parameters are larger for men with university degrees than for men who dropped out of school or finished year 12. Men with either a postgraduate degree, postgraduate diploma or a bachelors degree have a 24.7 percentage point higher chance to experience again an episode of depression the year after having experienced one episode. In contrast, for men with minimum or no schooling qualification this probability increase is only 16.6 percentage points. Men with university education in our sample are overall less likely to experience depression (5.5 percent) relative to men with minimum schooling (8.9 percent). This implies a 5.5 times higher chance of experiencing depression for men with higher education (448 percent increase from base probability), while it is less than 3 times for men with minimum schooling (188 percent increase from base probability). For women, we find the opposite, although the differences are much smaller.

A similar sex difference in the heterogeneity of state dependence is found between highly skilled and unskilled occupations. Men who work as legislators or professionals are more than 5 times, or 414 percent, more likely to experience another episode of depression (given the base probability), whereas men who work as manual or elementary workers are only less than twice, or 92 percent, more likely. In addition, experiencing twice an episode of depression in the past two years increases the risk of another episode by 34 percentage points for the skilled group, whereas it is only 15.5 percentage points for the unskilled group. For women, the exact opposite is observed: Highly skilled women are only twice as likely to experience another episode of depression (125 percent increase from base probability), whereas unskilled women are almost 3 times as likely (181 percent increase from base probability).

Last, we investigate whether particular age-groups are more prone to experience persisting depressive symptoms (columns (11)-(13)). The results suggest that individuals in their prime working age (30-59) are the most at risk of persisting symptoms of depression, and this holds for both men and women. However, the differences are less prominent when considering the cumulative effect of two episodes of depression.

It should be noted that these results are not sensitive to small variations in the cutoff values for dichotomising the mental health score into episodes of depression. We experimented with cut-off values ranging between 48 and 54, but the persistence estimates 
vary less than 2 percentage points for both sexes.

\section{Discussion and conclusion}

Do mental health problems beget future mental health problems? We ask to which degree exogenous shocks to mental health cause an individual's equilibrium mental health to drop indefinitely. Our analysis shows that the answer depends on where in the distribution these shocks occur. Averaging the effects over the full distribution of mental health yields little evidence of persistence in mental health problems once unobserved, individual-specific factors are controlled for. In the raw data, we find strong inter-temporal correlations of mental health of more than 0.6 , but these are reduced to roughly 0.1 in the preferred econometric specification (GMM-IV). These estimates are even smaller than the ones presented in Hauck and Rice (2004) who estimated a persistence parameter of 0.15 for men and 0.12 for women using the same method and British data. Hauck and Rice (2004) interpret their estimates as little evidence for persistence in mental health problems and we agree with their conclusion. In a simulation exercise we show that individuals revert back to their initial level of mental health almost instantaneously after the experience of a mental health shock. This is a surprising result, because it contradicts the hypothesis that mental health shocks induce biological changes in the brain that make future mental health problems more likely (See Farb et al., 2011).

One explanation for such low persistence parameters is that our measure of mental health problems, which captures only symptoms reported in the past four weeks, is not representative of the individual's average mental health in one particular year. An individual who has experienced an episode of depression within a year may have been free of symptoms at the time of the interview. Medical research shows that 18 months is the upper limit of the duration of a usual spell of depression. Most untreated cases are estimated to be resolved before three months (Posternak and Miller, 2001). Another explanation is that the GMM-IV approach uses only within-individual variation in mental health. If an individual experiences a shock to mental health in one time period and reports the exact same mental health score in all following time periods, then this individual would not be included in the analysis. The estimation results obtained from the correlated random effects models, which exploit both within- and between-variation of the data (at the expense of stronger modelling assumptions), yield a substantially higher persistence 
parameter of about 0.3 .

Perhaps a more convincing explanation is that the GMM-IV model is based on the assumption that persistence in mental health is the same at any point in the mental health distribution. Shocks experienced at the high end of the mental health distribution are likely to have little impact on long-term mental health, whereas shocks experienced at the low end are likely to have strong effects. From a policy perspective, it is much more important to know to what degree individuals get stuck in the blues, i.e. if they experience a negative mental health shock they are pushed indefinitely below a minimum level of mental health. When considering shocks that occur at the lower end of the mental health distribution, which we interpret as episodes of depression, we find strong evidence for persistence in mental health. The probability of experiencing symptoms of depression is between two to five times, depending on the sample, greater for individuals who were in this state in the year before (state dependence). Our finding that state dependence of depression is so strong for individuals with low household incomes has particular policy relevance. This social gradient could be the result of lacking economic resources to buffer a mental health shock, such as attending or financing weekly counselling sessions. Controversial is our finding that men with higher levels of education or occupational rank appear to be more likely to be thrown off their equilibrium path when experiencing an episode of depression than men of low levels of education or occupational rank. Surprisingly, for women we find the opposite. Explanations for this sex-based difference are not straightforward, but it may be the case that men in higher occupational ranks experience greater psychological pressure than women to perform outstandingly or are less likely to seek help.

High persistence in depression implies a negative spiral of worsening mental health that may cause a large economic burden for individuals and society if left untreated. Its silently and slowly advancing nature has been shown to impair productivity, the ability to go to work or to stay employed (Ettner et al., 1997; Kessler et al., 2003). Mental health problems experienced during adolescence are associated with lower household income in adulthood (Goodman et al., 2011; Smith and Smith, 2010), and one pathway for this effect is that the early experience of depression increases the probability of dropping out of school or never making it into university (Johnston et al., 2011; Fletcher, 2010).

If episodes of depression lower earnings potentials in the long-run and if the risk of getting stuck in the blues is higher for men and women with lower incomes, then gov- 
ernment interventions should be explicitly targeted at low-income earners. Means-tested programs that give access to free counselling sessions exist, for instance, in New Zealand. 'Primary Solutions' is a government service which provides up to six sessions of therapy at no financial charge from a Primary-Solutions-contracted therapist for individuals with mild to moderate mental health issues and from disadvantaged backgrounds. In Australia, publicly-funded intervention programs exist, but are accessible to every patient in need. The so-called Better Access to Mental Health Care Initiative provides currently ten hours of individual counselling sessions and up to an additional ten hours in group-based psychological treatment sessions within a calendar year. Although free of charge, the offered counselling sessions provide less than one meeting per month with a trained counsellor, and therefore do no ensure regularity in treatment. Moreover, the number of hours have been reduced since November 2011 due to a combination of budget consolidation attempts of the Federal Government and the high cost of treatment of depression. ${ }^{11}$ If the free counselling sessions were provided only to low-income earners, then more hours could be provided to this group most at risk to get trapped in recurring episodes of depression. Although we find that men in higher occupational ranks are similarly prone to state dependence in depression, they are more likely to stem themselves the high cost of treatment.

\section{References}

American Psychiatric Association, 2000. Diagnostic and Statistical Manual of Mental disorders, Fourth Edition. Washington, DC, American Psychiatric Association.

Arellano, M., Bond, S., 1991. Some tests of specification for panel data: Monte carlo evidence and an application to employment equations. The Review of Economic Studies 58, 277-297.

Arellano, M., Bover, O., 1995. Another look at the instrumental variable estimation of error-components models. Journal of Econometrics 68, $29-51$.

Arulampalam, W., Stewart, M.B., 2009. Simplified implementation of the heckman estimator of the dynamic probit model and a comparison with alternative estimators. Oxford Bulletin of Economics and Statistics 71, 0305-9049.

Bago d'Uva, T., Doorslaer, E.V., Lindeboom, M., O’Donnell, O., 2008. Does reporting heterogeneity bias the measurement of health disparities? Health Economics 17, 351375 .

\footnotetext{
${ }^{11}$ The treatment of depression costs the Australian community over $\$ 600$ million each year. These numbers are taken from the BeyondBlue Initiative webpage, accessed on 15 May 2012, http://www. health.gov.au/internet/main/publishing.nsf/content/mental-beyond.
} 
Berwick, D.M., Murphy, J.M., Goldman, P.A., Ware, John E., J., Barsky, A.J., Weinstein, M.C., 1991. Performance of a five-item mental health screening test. Medical Care 29, pp. 169-176.

Blundell, R., Bond, S., 1998. Initial conditions and moment restrictions in dynamic panel data models. Journal of Econometrics 87, 115 - 143.

Butterworth, P., Crosier, T., 2004. The validity of the sf-36 in an australian national household survey: demonstrating the applicability of the household income and labour dynamics in australia (HILDA) survey to examination of health inequalities. BMC 4, 44 .

Card, D., Sullivan, D., 1988. Measuring the effect of subsidized training programs on movements in and out of employment. Econometrica 56, 497-530.

Contoyannis, P., Jones, A.M., Rice, N., 2004a. The dynamics of health in the british household panel survey. Journal of Applied Econometrics 19, 473-503.

Contoyannis, P., Jones, A.M., Rice, N., 2004b. Simulation-based inference in dynamic panel probit models:an application to health. Empirical Economics 29, 49-77.

Ettner, S., Frank, R., Kessler, R., 1997. The impact of psychiatric disorders on labor market outcomes. Industrial and Labor Relations Review 51, 64-81.

Farb, N.A., Anderson, A.K., Bloch, R.T., Segal, Z.V., 2011. Mood-linked responses in medial prefrontal cortex predict relapse in patients with recurrent unipolar depression. Biological Psychiatry 70, 366-372.

Ferrer-i-Carbonell, A., Frijters, P., 2004. How important is methodology for the estimates of the determinants of happiness. Economic Journal 114, 641-659.

Fletcher, J., 2010. Adolescent depression and educational attainment: results using sibling fixed effects. Health Economics 19, 855-871.

Goodman, A., Joyce, R., Smith, J., 2011. The long shadow cast by childhood physical and mental problems on adult life. Proceedings of the National Academy of Science 108, 6032-6037.

Gorman, J.M., 1996. Comorbid depression and anxiety spectrum disorders. Depression and Anxiety 4, 160-168.

Groom, G., Hickie, I., Davenport, T., 2003. Out Of Hospital, Out Of Mind! Report Detailing Mental Health Services in Australia in 2002 and Community Priorities for National Mental Health Policy for 2003-2008. Mental Health Council of Australia, Canberra.

Hauck, K., Rice, N., 2004. A longitudinal analysis of mental health. Health Economics 13, 981-1001.

Heckman, J.J., 1978. Simple statistical models for discrete panel data developed and applied to test the hypothesis of true state dependence against the hypothesis of spurious state dependence. Annales de l'Insee, 227-269. 
Heiss, F., 2011. Dynamics of self-rated health and selective mortality. Empirical Economics 40, 119-140.

Hsiao, C., 2003. Analysis of Panel Data. Cambridge University Press.

Johnston, D.W., Schurer, S., Shields, M.A., 2011. Evidence on the long shadow of poor mental health across three generations. IZA Discussion Paper 6014.

Kessler, R., Demler, P.B.O., Jin, R., Koretz, D., Merikangas, K., Rush, A., Walters, E., Wang, P., 2003. The epidemiology of major depressive disorder: results from the national comorbidity survey replication (ncs-r) 18, 3095-3105.

Klearman, G., Weissman, M., 1989. Increasing rates of depression. Journal of the American Medical Association 261, 2229-2235.

McGorry, P., 2005. Every me and every you: responding to the hidden challenge of mental illness in australia. Australasian Psychiatry 13, 3-15.

Mundlak, Y., 1978. On the pooling of time series and cross section data. Econometrica $46,69-85$.

Posternak, M.A., Miller, I., 2001. Untreated short-term course of major depression: a meta-analysis of outcomes from studies using wait-list control groups. Journal of Affective Disorders 66, 139 - 146.

Prager, L., 2009. Depression and suicide in children and adolescents. Pediatrics in Review 30, 199-205.

Pudney, S., 2008. The dynamics of perception: modelling subjective wellbeing in a short panel. Journal Of The Royal Statistical Society Series A 171, 21-40.

Rucci, P., Frank, E., Calugi, S., Miniati, M., Benvenuti, A., Wallace, M., Fagiolini, A., Maggi, L., Kupfer, D.J., Cassano, G.B., 2011. Incidence and predictors of relapse during continuation treatment of major depression with ssri, interpersonal psychotherapy, or their combination. Depression and Anxiety 28, 955-962.

Rutter, M., 2006. Genes and behaviour: Nature-nurture interplay explained. Blackwell, Oxford.

Silveira, E., Taft, C., Sundh, V., Waern, M., Palsson, S., Steen, B., 2005. Performance of the sf-36 health survey in screening for depressive and anxiety disorders in an elderly female swedish population. Quality of Life Research 14, 1263-1274.

Smith, J., Smith, G., 2010. Long-term economic costs of psychological problems during childhood. Social Science \& Medicine 71, 110-115.

Summerfield, M., 2010. User manual HILDA Release 9. Tech. rep., Melbourne Institute of Applied Economic and Social Research - The University of Melbourne, Melbourne.

Ware, J.E., Gandek, B., 1998. Overview of the sf-36 health survey and the international quality of life assessment (IQOLA) project. Journal of Clinical Epidemiology 51, 903912. 
Williams, J.M.G., Russell, I.T., Crane, C., Russell, D., Whitaker, C.J., et al., D.S.D., 2010. Staying well after depression: trial design and protocol. BMC Psychiatry 10, Open Access.

Wooldridge, J.M., 2005. Simple solutions to the initial conditions problem in dynamic, nonlinear panel data models with unobserved heterogeneity. Journal of Applied Econometrics 20, 39-54.

Wooldridge, J.M., 2009. Econometric analysis of cross section and panel data. MIT Press. 


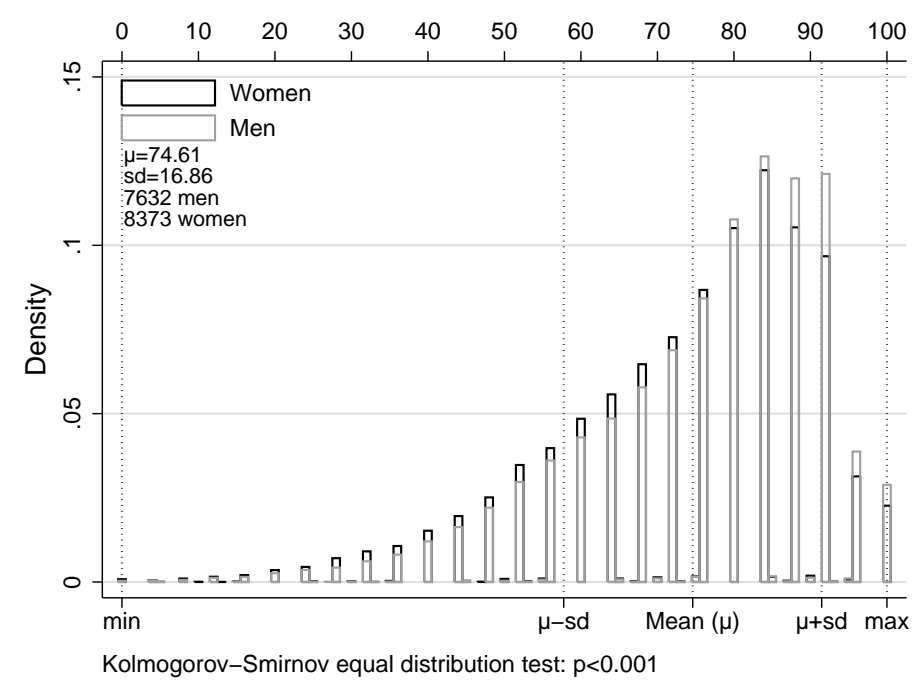

Figure 1: Distribution of mental health, by gender (HILDA 2001-2010) 
Table 1: Average inter-temporal correlations of mental health score

\begin{tabular}{cccccccccc}
\hline Wave & $\mathbf{1}$ & $\mathbf{2}$ & $\mathbf{3}$ & $\mathbf{4}$ & $\mathbf{5}$ & $\mathbf{6}$ & $\mathbf{7}$ & $\mathbf{8}$ & $\mathbf{9}$ \\
\cline { 2 - 9 } $\mathbf{1}$ & $\mathbf{1}$ & & & & & & & & \\
$\mathbf{2}$ & 0.642 & 1 & & & & & & & \\
$\mathbf{3}$ & 0.604 & 0.644 & $\mathbf{1}$ & & & & & & \\
$\mathbf{4}$ & 0.579 & 0.601 & 0.643 & $\mathbf{1}$ & & & & & \\
$\mathbf{5}$ & 0.565 & 0.581 & 0.603 & 0.643 & 1 & & & & \\
$\mathbf{6}$ & 0.551 & 0.563 & 0.580 & 0.598 & 0.639 & 1 & & & \\
$\mathbf{7}$ & 0.536 & 0.550 & 0.565 & 0.575 & 0.592 & 0.636 & 1 & & \\
$\mathbf{8}$ & 0.527 & 0.533 & 0.552 & 0.561 & 0.572 & 0.587 & 0.631 & 1 & \\
$\mathbf{9}$ & 0.514 & 0.518 & 0.524 & 0.536 & 0.550 & 0.555 & 0.581 & 0.624 & 1 \\
$\mathbf{1 0}$ & 0.488 & 0.497 & 0.497 & 0.495 & 0.521 & 0.534 & 0.537 & 0.564 & 0.614 \\
\hline
\end{tabular}

Sample averages taken over years 2001-2010. Men and women pooled.

Table 2: Average transition probabilities between quintiles of mental health score

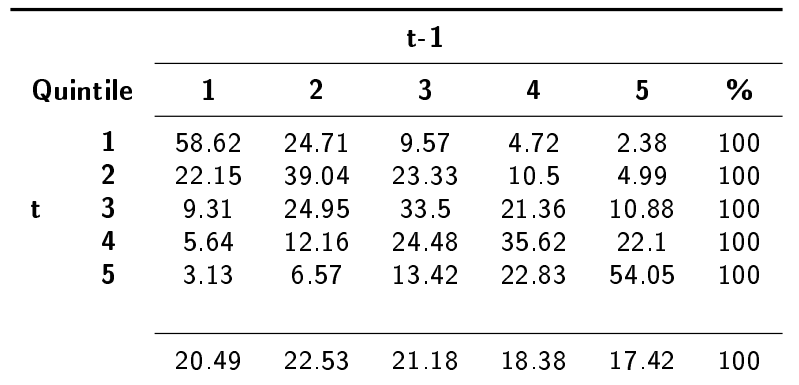

Average transition probabilities between quintiles of 5-item mental health score calculated across 2001-2010. Men and women pooled. 
Table 3: Persistence in mental health problems: Estimated persistence parameters from different model specifications using full estimation sample

\begin{tabular}{|c|c|c|c|c|}
\hline & AB & $\mathrm{CRE}+\mathrm{IC}$ & CRE & OLS \\
\hline \multicolumn{5}{|l|}{ Men } \\
\hline Mental health (t-1) & $\begin{array}{c}0.0961 * * * \\
(0.0148)\end{array}$ & $\begin{array}{c}0.299 * * * \\
(0.00895)\end{array}$ & $\begin{array}{c}0.365^{* * *} \\
(0.00843)\end{array}$ & $\begin{array}{c}0.440 * * * \\
(0.00817)\end{array}$ \\
\hline Mental health (t-2) & $\begin{array}{c}0.0175^{*} \\
(0.0101)\end{array}$ & $\begin{array}{c}0.205^{* * *} \\
(0.00927)\end{array}$ & $\begin{array}{l}0.278 * * * \\
(0.00883)\end{array}$ & $\begin{array}{l}0.317 * * * \\
(0.00845)\end{array}$ \\
\hline Mental health $(\mathrm{t}=0)$ & & $\begin{array}{c}0.247^{* * *} \\
(0.00985)\end{array}$ & & \\
\hline Constant & & $\begin{array}{c}-0.504^{* *} \\
(0.244)\end{array}$ & $\begin{array}{c}-0.314 \\
(0.238)\end{array}$ & $\begin{array}{c}-0.0909 \\
(0.152)\end{array}$ \\
\hline Observations & 20,302 & 20,302 & 20,302 & 20,302 \\
\hline Individuals & 4,968 & 4,968 & 4,968 & 4,968 \\
\hline R-squared & & & & 0.515 \\
\hline Sargan over-identification test ( $\mathrm{p}$-value) & 0.408 & & & \\
\hline First-order serial correlation test ( $p$-value) & 0.000 & & & \\
\hline Second-order serial correlation test ( $p$-value) & 0.081 & & & \\
\hline Rho & & 0.132 & 0.136 & \\
\hline \multicolumn{5}{|l|}{ Women } \\
\hline Mental health (t-1) & $\begin{array}{c}0.103^{* * *} \\
(0.0131)\end{array}$ & $\begin{array}{c}0.320 * * * \\
(0.00795)\end{array}$ & $\begin{array}{c}0.377 * * * \\
(0.00728)\end{array}$ & $\begin{array}{c}0.420 * * * \\
(0.00714)\end{array}$ \\
\hline Mental health (t-2) & $\begin{array}{c}0.0256 * * * \\
(0.00912)\end{array}$ & $\begin{array}{l}0.224^{* * *} \\
(0.00808)\end{array}$ & $\begin{array}{c}0.292^{* * *} \\
(0.00753)\end{array}$ & $\begin{array}{l}0.316 * * * \\
(0.00730)\end{array}$ \\
\hline Mental health $(\mathrm{t}=0)$ & & $\begin{array}{c}0.208^{* * * *} \\
(0.00819)\end{array}$ & & \\
\hline Constant & & $\begin{array}{c}0.00424 \\
(0.202)\end{array}$ & $\begin{array}{c}-0.0424 \\
(0.192)\end{array}$ & $\begin{array}{c}0.113 \\
(0.129)\end{array}$ \\
\hline Observations & 23,839 & 23,839 & 23,839 & 23,839 \\
\hline Individuals & 5,718 & 5,718 & 5,718 & 5,718 \\
\hline R-squared & & & & 0.480 \\
\hline Sargan over-identification test ( $p$-value) & 0.0926 & & & \\
\hline First-order serial correlation test ( $\mathrm{p}$-value) & 0.000 & & & \\
\hline Second-order serial correlation test ( $p$-value) & 0.852 & & & \\
\hline Rho & & 0.0687 & 0.0720 & \\
\hline
\end{tabular}

Standard errors in parentheses. AB refers to the Arellano-Bond estimator (System GMM-IV). CRE refers to the correlated random effects model (Mundlak adjustment of the error term); Rho measures the share of individualspecific variation in the total unexplained variation. ${ }^{*} p<0.1,{ }^{* *} p<0.05, * * * p<0.01$.

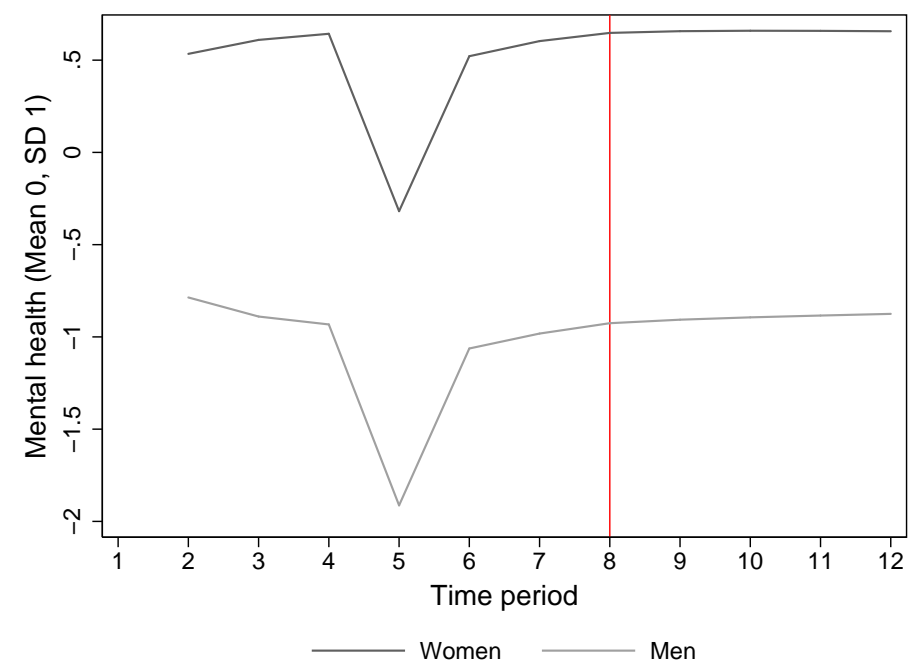

Figure 2: Adjustment path of a one-SD shock to mental health for men and women 


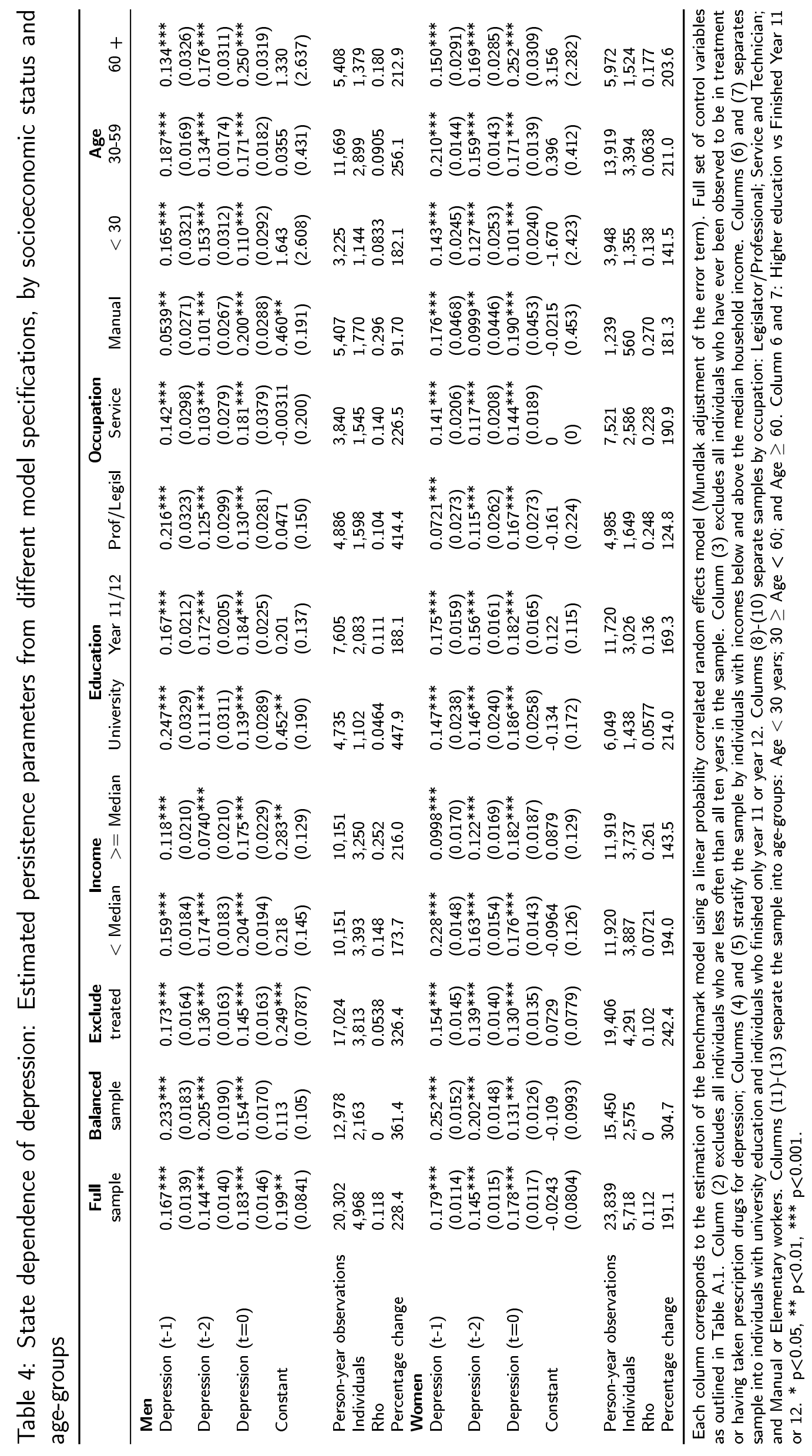




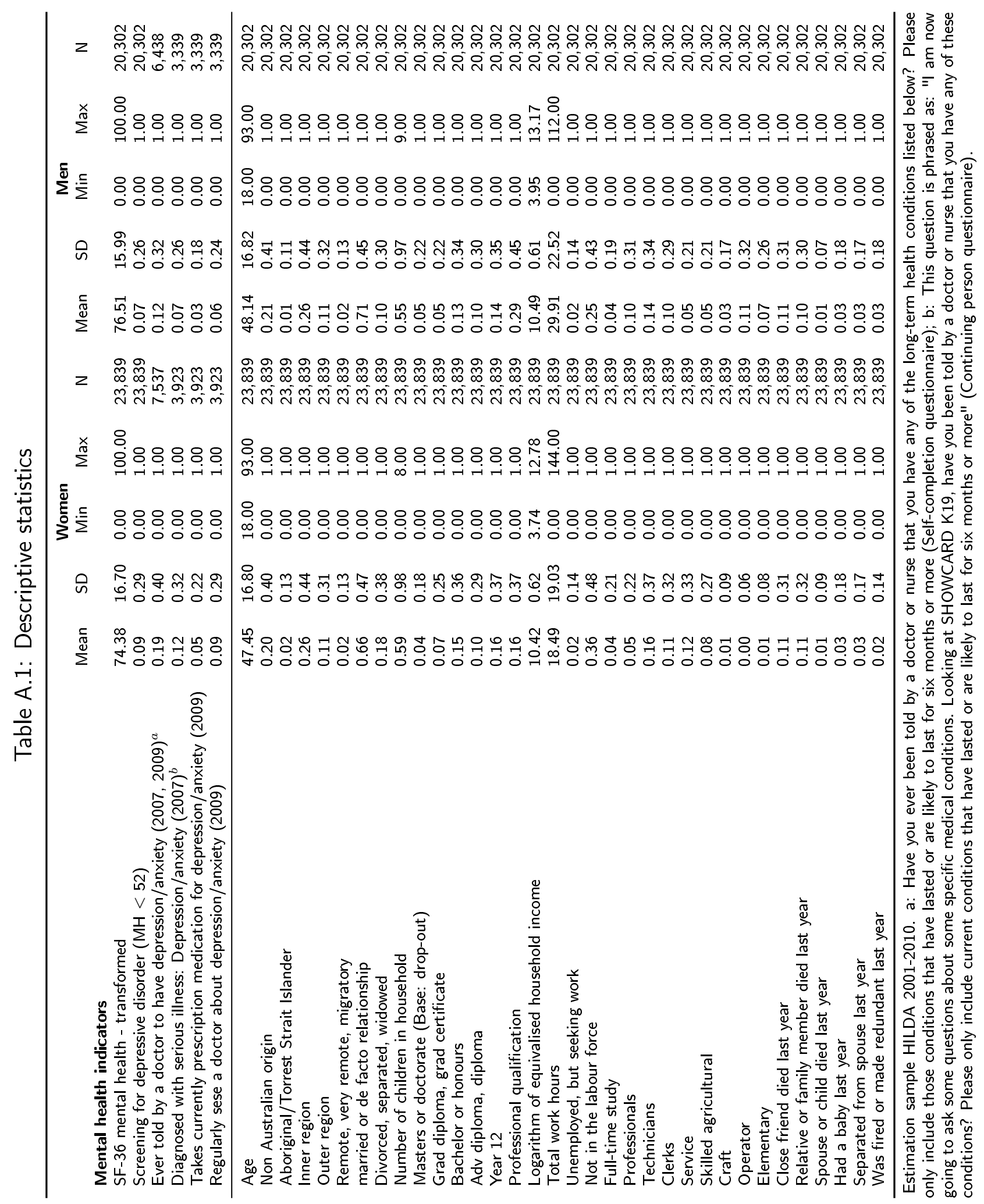


Table A.2: Estimated persistence parameters of mental health problems: Full estimation results for different model specifications

\begin{tabular}{|c|c|c|c|c|c|c|}
\hline & \multicolumn{3}{|c|}{ Women } & \multicolumn{3}{|c|}{ Men } \\
\hline & $\begin{array}{c}\mathbf{A B}^{a} \\
\mathbf{M H}^{c} \\
(0,100)\end{array}$ & $\begin{array}{c}\mathrm{CRE}^{b} \\
\mathrm{MH} \\
(0,100)\end{array}$ & $\begin{array}{c}\text { CRE } \\
\text { Depression } \\
(0,1)\end{array}$ & $\begin{array}{c}A B \\
M H \\
(0,100)\end{array}$ & $\begin{array}{c}\text { CRE } \\
\text { MH } \\
(0,100)\end{array}$ & $\begin{array}{c}\text { CRE } \\
\text { Depression } \\
(0,1)\end{array}$ \\
\hline Lag 1 & $\begin{array}{l}0.103 * * * \\
(0.0131)\end{array}$ & $\begin{array}{l}0.320 * * * \\
(0.00795)\end{array}$ & $\begin{array}{l}0.179 * * * \\
(0.0114)\end{array}$ & $\begin{array}{l}0.0961 * * * \\
(0.0148)\end{array}$ & $\begin{array}{l}0.299^{* * *} \\
(0.00895)\end{array}$ & $\begin{array}{l}0.167 * * * \\
(0.0139)\end{array}$ \\
\hline Lag 2 & $\begin{array}{l}0.0256^{* * *} \\
(0.00912)\end{array}$ & $\begin{array}{l}0.224^{* * *} \\
(0.00808)\end{array}$ & $\begin{array}{l}0.145 * * * \\
(0.0115)\end{array}$ & $\begin{array}{l}0.0175^{*} \\
(0.0101)\end{array}$ & $\begin{array}{l}0.205 * * * \\
(0.00927)\end{array}$ & $\begin{array}{l}0.144^{* * *} \\
(0.0140)\end{array}$ \\
\hline Initial condition & & $\begin{array}{l}0.208 * * * \\
(0.00819)\end{array}$ & $\begin{array}{l}0.178 * * * \\
(0.0117)\end{array}$ & & $\begin{array}{l}0.247 * * * \\
(0.00985)\end{array}$ & $\begin{array}{l}0.183 * * * \\
(0.0146)\end{array}$ \\
\hline Age & $\begin{array}{l}-0.0198 \\
(0.0407)\end{array}$ & $\begin{array}{l}-0.0372 \\
(0.0244)\end{array}$ & $\begin{array}{l}0.00714 \\
(0.00934)\end{array}$ & $\begin{array}{l}-0.00414 \\
(0.0464)\end{array}$ & $\begin{array}{l}-0.0495^{*} \\
(0.0264)\end{array}$ & $\begin{array}{l}0.0146 \\
(0.00955)\end{array}$ \\
\hline Age square & $\begin{array}{l}0.000832 \\
(0.000648)\end{array}$ & $\begin{array}{l}0.000852 * \\
(0.000467)\end{array}$ & $\begin{array}{l}-0.000188 \\
(0.000177)\end{array}$ & $\begin{array}{l}0.000820 \\
(0.000752)\end{array}$ & $\begin{array}{l}0.00118^{* *} \\
(0.000507)\end{array}$ & $\begin{array}{l}-0.000247 \\
(0.000178)\end{array}$ \\
\hline Age cube & $\begin{array}{l}-7.60 \mathrm{e}-06^{*} \\
(4.06 \mathrm{e}-06)\end{array}$ & $\begin{array}{l}-5.43 \mathrm{e}-06^{*} \\
(2.94 \mathrm{e}-06)\end{array}$ & $\begin{array}{l}1.20 \mathrm{e}-06 \\
(1.11 \mathrm{e}-06)\end{array}$ & $\begin{array}{l}-6.68 \mathrm{e}-06 \\
(4.61 \mathrm{e}-06)\end{array}$ & $\begin{array}{l}-8.38 \mathrm{e}-06^{* * *} \\
(3.23 \mathrm{e}-06)\end{array}$ & $\begin{array}{l}1.42 e-06 \\
(1.11 e-06)\end{array}$ \\
\hline Foreigner & & $\begin{array}{l}-0.0198 \\
(0.0122)\end{array}$ & $\begin{array}{l}0.00531 \\
(0.00501)\end{array}$ & & $\begin{array}{l}-0.0158 \\
(0.0144)\end{array}$ & $\begin{array}{l}0.00257 \\
(0.00490)\end{array}$ \\
\hline ATSI & & $\begin{array}{l}-0.00625 \\
(0.0450)\end{array}$ & $\begin{array}{l}0.00530 \\
(0.0195)\end{array}$ & & $\begin{array}{l}0.106 * * \\
(0.0526)\end{array}$ & $\begin{array}{l}-0.0588^{* * *} \\
(0.0157)\end{array}$ \\
\hline Inner region & $\begin{array}{l}0.0386 \\
(0.0432)\end{array}$ & $\begin{array}{l}0.0309 \\
(0.0367)\end{array}$ & $\begin{array}{l}0.00982 \\
(0.0132)\end{array}$ & $\begin{array}{l}0.0503 \\
(0.0461)\end{array}$ & $\begin{array}{l}0.0337 \\
(0.0418)\end{array}$ & $\begin{array}{c}-0.0199 \\
(0.0135)\end{array}$ \\
\hline Outer region & $\begin{array}{l}-0.0616 \\
(0.0651)\end{array}$ & $\begin{array}{l}-0.0245 \\
(0.0552)\end{array}$ & $\begin{array}{l}0.0415^{* *} \\
(0.0197)\end{array}$ & $\begin{array}{l}0.0599 \\
(0.0699)\end{array}$ & $\begin{array}{l}0.0793 \\
(0.0661)\end{array}$ & $\begin{array}{l}0.0161 \\
(0.0224)\end{array}$ \\
\hline Remote area & $\begin{array}{l}0.0503 \\
(0.103)\end{array}$ & $\begin{array}{l}0.0872 \\
(0.0860)\end{array}$ & $\begin{array}{l}0.0366 \\
(0.0330)\end{array}$ & $\begin{array}{l}0.00697 \\
(0.121)\end{array}$ & $\begin{array}{l}-0.0254 \\
(0.103)\end{array}$ & $\begin{array}{l}0.0501 \\
(0.0398)\end{array}$ \\
\hline Married & $\begin{array}{l}0.0447 \\
(0.0428)\end{array}$ & $\begin{array}{l}0.0227 \\
(0.0365)\end{array}$ & $\begin{array}{l}-0.0154 \\
(0.0142)\end{array}$ & $\begin{array}{l}0.0173 \\
(0.0438)\end{array}$ & $\begin{array}{l}0.00468 \\
(0.0380)\end{array}$ & $\begin{array}{c}-0.00993 \\
(0.0130)\end{array}$ \\
\hline Divorced & $\begin{array}{l}0.0400 \\
(0.0608)\end{array}$ & $\begin{array}{l}0.115^{* *} \\
(0.0546)\end{array}$ & $\begin{array}{l}-0.00287 \\
(0.0215)\end{array}$ & $\begin{array}{l}-0.123^{*} \\
(0.0646)\end{array}$ & $\begin{array}{l}-0.0444 \\
(0.0600)\end{array}$ & $\begin{array}{l}0.000482 \\
(0.0204)\end{array}$ \\
\hline Number of children & $\begin{array}{l}-0.0146 \\
(0.0172)\end{array}$ & $\begin{array}{l}0.00445 \\
(0.0118)\end{array}$ & $\begin{array}{l}-0.00652 \\
(0.00461)\end{array}$ & $\begin{array}{l}-0.00870 \\
(0.0165)\end{array}$ & $\begin{array}{l}0.00622 \\
(0.0115)\end{array}$ & $\begin{array}{r}-0.000499 \\
(0.00391)\end{array}$ \\
\hline Postgraduate degree & $\begin{array}{l}-0.152 \\
(0.590)\end{array}$ & $\begin{array}{l}0.0592 \\
(0.102)\end{array}$ & $\begin{array}{l}-0.00998 \\
(0.0336)\end{array}$ & $\begin{array}{l}0.750 \\
(0.678)\end{array}$ & $\begin{array}{l}-0.0422 \\
(0.145)\end{array}$ & $\begin{array}{l}0.0503 \\
(0.0533)\end{array}$ \\
\hline Graduate Diploma & $\begin{array}{l}-0.480 \\
(0.439)\end{array}$ & $\begin{array}{l}-0.0355 \\
(0.0881)\end{array}$ & $\begin{array}{l}-0.0184 \\
(0.0332)\end{array}$ & $\begin{array}{l}0.196 \\
(0.550)\end{array}$ & $\begin{array}{r}-0.0845 \\
(0.124)\end{array}$ & $\begin{array}{l}0.000232 \\
(0.0463)\end{array}$ \\
\hline Bachelor degree & $\begin{array}{l}-0.479 \\
(0.329)\end{array}$ & $\begin{array}{l}-0.00841 \\
(0.0802)\end{array}$ & $\begin{array}{l}-0.0157 \\
(0.0297)\end{array}$ & $\begin{array}{r}-0.0328 \\
(0.392)\end{array}$ & $\begin{array}{l}-0.000870 \\
(0.100)\end{array}$ & $\begin{array}{l}-0.0289 \\
(0.0339)\end{array}$ \\
\hline Diploma & $\begin{array}{l}-0.376 \\
(0.370)\end{array}$ & $\begin{array}{l}0.0118 \\
(0.0840)\end{array}$ & $\begin{array}{l}-0.00791 \\
(0.0312)\end{array}$ & $\begin{array}{l}-0.602 \\
(0.494)\end{array}$ & $\begin{array}{l}-0.0811 \\
(0.108)\end{array}$ & $\begin{array}{l}0.00377 \\
(0.0384)\end{array}$ \\
\hline Finished year 12 & $\begin{array}{l}-0.0940 \\
(0.121)\end{array}$ & $\begin{array}{l}-0.0809 \\
(0.0605)\end{array}$ & $\begin{array}{l}0.00804 \\
(0.0220)\end{array}$ & $\begin{array}{l}-0.0412 \\
(0.135)\end{array}$ & $\begin{array}{l}0.00238 \\
(0.0698)\end{array}$ & $\begin{array}{l}-0.0176 \\
(0.0225)\end{array}$ \\
\hline Any professional training & $\begin{array}{l}-0.0222 \\
(0.196)\end{array}$ & $\begin{array}{l}-0.0741 \\
(0.0562)\end{array}$ & $\begin{array}{l}0.0328 \\
(0.0206)\end{array}$ & $\begin{array}{l}-0.288 \\
(0.267)\end{array}$ & $\begin{array}{l}0.0384 \\
(0.0809)\end{array}$ & $\begin{array}{l}-0.0136 \\
(0.0252)\end{array}$ \\
\hline Household income (In) & $\begin{array}{l}-0.0283 \\
(0.0615)\end{array}$ & $\begin{array}{l}0.0138 \\
(0.0130)\end{array}$ & $\begin{array}{l}-0.00119 \\
(0.00496)\end{array}$ & $\begin{array}{l}-0.0130 \\
(0.0567)\end{array}$ & $\begin{array}{l}0.0229 \\
(0.0144)\end{array}$ & $\begin{array}{l}-0.00128 \\
(0.00509)\end{array}$ \\
\hline Work-hours & $\begin{array}{l}-0.00102 \\
(0.00242)\end{array}$ & $\begin{array}{l}-0.000266 \\
(0.000727)\end{array}$ & $\begin{array}{l}-0.000360 \\
(0.000253)\end{array}$ & $\begin{array}{l}0.00134 \\
(0.00273)\end{array}$ & $\begin{array}{l}0.000180 \\
(0.000735)\end{array}$ & $\begin{array}{l}-0.000674^{* * *} \\
(0.000258)\end{array}$ \\
\hline Unemployment & $\begin{array}{l}-0.271 \\
(0.218)\end{array}$ & $\begin{array}{l}-0.116 * * \\
(0.0583)\end{array}$ & $\begin{array}{l}0.0381^{*} \\
(0.0225)\end{array}$ & $\begin{array}{l}-0.264 \\
(0.224)\end{array}$ & $\begin{array}{l}-0.109^{*} \\
(0.0663)\end{array}$ & $\begin{array}{l}-0.00934 \\
(0.0247)\end{array}$ \\
\hline Not in the labour force & $\begin{array}{l}-0.0316 \\
(0.131)\end{array}$ & $\begin{array}{l}-0.0459 \\
(0.0400)\end{array}$ & $\begin{array}{l}0.0147 \\
(0.0159)\end{array}$ & $\begin{array}{l}-0.287^{*} \\
(0.168)\end{array}$ & $\begin{array}{l}-0.0743 \\
(0.0494)\end{array}$ & $\begin{array}{l}0.00535 \\
(0.0170)\end{array}$ \\
\hline Full-time study & $\begin{array}{l}-0.500^{* *} \\
(0.225)\end{array}$ & $\begin{array}{l}-0.0809 \\
(0.0528)\end{array}$ & $\begin{array}{l}0.00348 \\
(0.0204)\end{array}$ & $\begin{array}{l}-0.106 \\
(0.219)\end{array}$ & $\begin{array}{l}-0.0346 \\
(0.0582)\end{array}$ & $\begin{array}{c}-0.0361^{*} \\
(0.0200)\end{array}$ \\
\hline Legislator & $\begin{array}{l}0.0565 \\
(0.168)\end{array}$ & $\begin{array}{r}-0.00219 \\
(0.0443)\end{array}$ & $\begin{array}{l}0.000718 \\
(0.0172)\end{array}$ & $\begin{array}{r}-0.0317 \\
(0.156)\end{array}$ & $\begin{array}{r}-0.00414 \\
(0.0424)\end{array}$ & $\begin{array}{c}-0.0139 \\
(0.0129)\end{array}$ \\
\hline Professional & $\begin{array}{r}-0.0391 \\
(0.150)\end{array}$ & $\begin{array}{l}0.0209 \\
(0.0409)\end{array}$ & $\begin{array}{l}-0.0149 \\
(0.0164)\end{array}$ & $\begin{array}{l}-0.127 \\
(0.157)\end{array}$ & $\begin{array}{l}-0.0380 \\
(0.0460)\end{array}$ & $\begin{array}{r}-0.00532 \\
(0.0146)\end{array}$ \\
\hline Technician & $\begin{array}{l}-0.110 \\
(0.144)\end{array}$ & $\begin{array}{l}0.0205 \\
(0.0394)\end{array}$ & $\begin{array}{r}-0.00313 \\
(0.0155)\end{array}$ & $\begin{array}{l}-0.114 \\
(0.157)\end{array}$ & $\begin{array}{c}-0.0293 \\
(0.0414)\end{array}$ & $\begin{array}{r}-0.00701 \\
(0.0132)\end{array}$ \\
\hline Clerks & $\begin{array}{l}0.0330 \\
(0.145)\end{array}$ & $\begin{array}{r}-0.00775 \\
(0.0388)\end{array}$ & $\begin{array}{l}0.00391 \\
(0.0154)\end{array}$ & $\begin{array}{l}-0.208 \\
(0.170)\end{array}$ & $\begin{array}{l}0.00291 \\
(0.0459)\end{array}$ & $\begin{array}{c}-0.00183 \\
(0.0163)\end{array}$ \\
\hline Service & $\begin{array}{l}-0.131 \\
(0.137)\end{array}$ & $\begin{array}{l}-0.0453 \\
(0.0399)\end{array}$ & $\begin{array}{l}-0.00301 \\
(0.0165)\end{array}$ & $\begin{array}{l}-0.330^{*} \\
(0.183)\end{array}$ & $\begin{array}{l}0.0243 \\
(0.0494)\end{array}$ & $\begin{array}{l}-0.0149 \\
(0.0161)\end{array}$ \\
\hline Skilled agricultural & $\begin{array}{l}-0.271 \\
(0.250)\end{array}$ & $\begin{array}{l}-0.141^{*} \\
(0.0759)\end{array}$ & $\begin{array}{c}-0.00874 \\
(0.0303)\end{array}$ & $\begin{array}{l}-0.323^{*} \\
(0.183)\end{array}$ & $\begin{array}{l}0.0472 \\
(0.0604)\end{array}$ & $\begin{array}{l}-0.00107 \\
(0.0194)\end{array}$ \\
\hline Operator & $\begin{array}{l}0.458 \\
(0.316)\end{array}$ & $\begin{array}{l}0.0649 \\
(0.0990)\end{array}$ & $\begin{array}{l}0.00225 \\
(0.0398)\end{array}$ & $\begin{array}{l}-0.0273 \\
(0.154)\end{array}$ & $\begin{array}{l}0.0530 \\
(0.0414)\end{array}$ & $\begin{array}{l}-0.0198 \\
(0.0128)\end{array}$ \\
\hline Elementary worker & $\begin{array}{l}-0.288 \\
(0.290)\end{array}$ & $\begin{array}{c}-0.0119 \\
(0.0685)\end{array}$ & $\begin{array}{l}0.0201 \\
(0.0269)\end{array}$ & $\begin{array}{l}-0.319^{* *} \\
(0.160)\end{array}$ & $\begin{array}{c}-0.0233 \\
(0.0428)\end{array}$ & $\begin{array}{l}0.0220 \\
(0.0156)\end{array}$ \\
\hline Friend died last year & $\begin{array}{l}0.000374 \\
(0.0168)\end{array}$ & $\begin{array}{l}-0.0113 \\
(0.0150)\end{array}$ & $\begin{array}{l}0.00382 \\
(0.00549)\end{array}$ & $\begin{array}{c}-0.0290^{*} \\
(0.0173)\end{array}$ & $\begin{array}{l}-0.0470^{* * *} \\
(0.0151)\end{array}$ & $\begin{array}{l}0.00413 \\
(0.00523)\end{array}$ \\
\hline Relative died last year & $\begin{array}{l}-0.0609^{* * *} \\
(0.0158)\end{array}$ & $\begin{array}{l}-0.0549^{* * *} \\
(0.0152)\end{array}$ & $\begin{array}{l}0.00546 \\
(0.00562)\end{array}$ & $\begin{array}{l}-0.0113 \\
(0.0170)\end{array}$ & $\begin{array}{l}-0.0115 \\
(0.0157)\end{array}$ & $\begin{array}{l}0.000980 \\
(0.00523)\end{array}$ \\
\hline Spouse/child died last year & $\begin{array}{l}-0.355^{* * *} \\
(0.0588)\end{array}$ & $\begin{array}{l}-0.364^{* * *} \\
(0.0717)\end{array}$ & $\begin{array}{l}0.0493^{* *} \\
(0.0246)\end{array}$ & $\begin{array}{l}-0.204^{* * *} \\
(0.0720)\end{array}$ & $\begin{array}{c}-0.202 * * \\
(0.0789)\end{array}$ & $\begin{array}{l}0.0292 \\
(0.0293)\end{array}$ \\
\hline Birth of baby last year & $\begin{array}{l}-0.0266 \\
(0.0338)\end{array}$ & $\begin{array}{l}0.0162 \\
(0.0298)\end{array}$ & $\begin{array}{l}-0.0235^{* *} \\
(0.0103)\end{array}$ & $\begin{array}{l}-0.0218 \\
(0.0296)\end{array}$ & $\begin{array}{l}0.0258 \\
(0.0277)\end{array}$ & $\begin{array}{l}-0.0138 \\
(0.00872)\end{array}$ \\
\hline Separated from spouse last year & $\begin{array}{l}-0.171^{* * *} \\
(0.0314)\end{array}$ & $\begin{array}{l}-0.228^{* * *} \\
(0.0356)\end{array}$ & $\begin{array}{l}0.0577 * * * \\
(0.0144)\end{array}$ & $\begin{array}{c}-0.162 * * * \\
(0.0330)\end{array}$ & $\begin{array}{l}-0.217 * * * \\
(0.0401)\end{array}$ & $\begin{array}{l}0.0803^{* * *} \\
(0.0158)\end{array}$ \\
\hline Fired/made redundant last year & $\begin{array}{c}-0.0178 \\
(0.0427)\end{array}$ & $\begin{array}{l}-0.106 * * * \\
(0.0405)\end{array}$ & $\begin{array}{l}0.0361^{* *} \\
(0.0159)\end{array}$ & $\begin{array}{l}0.0241 \\
(0.0359)\end{array}$ & $\begin{array}{c}-0.0591^{*} \\
(0.0343)\end{array}$ & $\begin{array}{l}0.0291^{* *} \\
(0.0122)\end{array}$ \\
\hline Constant & & $\begin{array}{l}0.00424 \\
(0.202)\end{array}$ & $\begin{array}{l}-0.0243 \\
(0.0804)\end{array}$ & & $\begin{array}{l}-0.504^{* *} \\
(0.244)\end{array}$ & $\begin{array}{l}0.199^{* *} \\
(0.0841)\end{array}$ \\
\hline $\begin{array}{l}\text { Person-year observations } \\
\text { Individuals }\end{array}$ & $\begin{array}{l}23,839 \\
5,718\end{array}$ & $\begin{array}{l}23,839 \\
5,718\end{array}$ & $\begin{array}{l}23,839 \\
5,718\end{array}$ & $\begin{array}{l}20,302 \\
4,968\end{array}$ & 20,302 & $\begin{array}{l}20,302 \\
4,968\end{array}$ \\
\hline
\end{tabular}

${ }^{*} \mathrm{p}<0.05,{ }^{* *} \mathrm{p}<0.01,{ }^{* * *} \mathrm{p}<0.001$; a AB: Arellano-Bond estimator; b CRE: Correlated random effects estimator. c MH: Mental health. Estimated coefficients on time effects and mean values of all time-varying variables which are used in the correlated random health. Estimated coefficients on time effects and mean values of all time-varying 
Table A.3: Estimation results: Dynamics in mental health

\begin{tabular}{|c|c|c|c|c|c|c|c|}
\hline & CRE-No Dyn & OLS & CRE-Dyn & CRE-Dyn-IC & $\mathbf{A H}$ & AB 1 & AB 2 \\
\hline \multicolumn{8}{|l|}{ Men } \\
\hline Mental health (t-1) & & $\begin{array}{c}0.646 * * * \\
(0.00862)\end{array}$ & $\begin{array}{c}0.502^{* * * *} \\
(0.00984)\end{array}$ & $\begin{array}{c}0.370 * * * \\
(0.0103)\end{array}$ & $\begin{array}{c}0.502 * * * \\
(0.00182)\end{array}$ & $\begin{array}{c}0.0970 * * * \\
(0.0115)\end{array}$ & $\begin{array}{c}0.0761^{* * *} \\
(0.0112)\end{array}$ \\
\hline Mental health $(t=0)$ & & & & $\begin{array}{c}0.323^{* * *} \\
(0.0105)\end{array}$ & & & \\
\hline Constant & $\begin{array}{l}-0.699 \\
(0.476)\end{array}$ & $\begin{array}{l}-0.0943 \\
(0.164)\end{array}$ & $\begin{array}{l}-0.403 \\
(0.274)\end{array}$ & $\begin{array}{c}-0.619 * * \\
(0.268)\end{array}$ & $\begin{array}{c}-0.0426 * * * \\
(0.0137)\end{array}$ & & \\
\hline Person-year observations & 20,302 & 20,302 & 20,302 & 20,302 & 20,302 & 20,302 & 20,302 \\
\hline Individuals & 4,968 & 4968 & 4968 & 4968 & 4968 & 4968 & 4968 \\
\hline R-squared & . & 0.459 & & & 0.718 & & \\
\hline Number of id & & & 4,968 & 4,968 & & 4,968 & 4,968 \\
\hline Rho & .642 & & 0.143 & 0.134 & & & \\
\hline Sargan Test (p-value) & & & & & & 0.006 & 0.028 \\
\hline$A B$ serial correlation test ( $p$-value) & & & & & & 0.002 & 0.028 \\
\hline Mental health $(\mathrm{t}-1)$ & & $\begin{array}{c}0.616 * * * \\
(0.00778)\end{array}$ & $\begin{array}{c}0.526 * * * \\
(0.00853)\end{array}$ & $\begin{array}{c}0.402^{* * *} \\
(0.00936)\end{array}$ & $\begin{array}{c}0.503 * * * \\
(0.00158)\end{array}$ & $\begin{array}{c}0.0931^{* * *} \\
(0.0104)\end{array}$ & $\begin{array}{c}0.0758 * * * \\
(0.0103)\end{array}$ \\
\hline Mental health $(\mathrm{t}=0)$ & & & & $\begin{array}{c}0.285^{* * *} \\
(0.00871)\end{array}$ & & & \\
\hline Constant & $\begin{array}{c}-1.035 * * \\
(0.411)\end{array}$ & $\begin{array}{l}0.0242 \\
(0.141)\end{array}$ & $\begin{array}{l}-0.329 \\
(0.226)\end{array}$ & $\begin{array}{l}-0.170 \\
(0.227)\end{array}$ & $\begin{array}{c}-0.0198 \\
(0.0135)\end{array}$ & & \\
\hline Person-year observations & 23,839 & 23,839 & 23,839 & 23,839 & 23,839 & 23,839 & 23,839 \\
\hline Individuals & 5,718 & 5,718 & 5,718 & 5,718 & 5,718 & 5,718 & 5,718 \\
\hline R-squared & 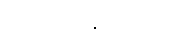 & 0.422 & & & 0.723 & & \\
\hline Rho & .600 & & 0.081 & 0.073 & & & \\
\hline Sargan Test ( $p$-value) & & & & & & 0.001 & 0.010 \\
\hline$A B$ serial correlation test ( $p$-value) & & & & & & 0.047 & 0.157 \\
\hline
\end{tabular}

Standard errors in parentheses. CRE: Correlated random effects model (Mundlak adjustment of the error term). CRE-No dyn-IC: Correlated random effects model (Mundlak adjustment of the error term including an indicator of initial conditions). AH: Anderson and Hisao estimator; AB 1: Arellano-Bond estimator assuming all covariates to be strictly exogenous. AB 2: Assuming education, occupation, and income to be endogenous. All models include the same set of control variables as described in Table A.1. ${ }^{*} p<0.1,{ }^{* *} p<0.05,{ }^{* * *} p<0.01$ 